\title{
The Perception of Individual Taxpayers in Jakarta Towards Tax Compliance with Tax Attitude as a Moderating Variable
}

\author{
Syanti Dewi ${ }^{1 *}$, Widyasari ${ }^{1}$, Nataherwin ${ }^{1}$ \\ ${ }^{1}$ Accounting Program, Faculty of Economics and Business, Universitas Tarumanagara, Jakarta, 11470, Indonesia \\ "Corresponding author. Email: syantid@fe.untar.ac.id
}

\begin{abstract}
This study aimed to see whether there is an effect of taxpayer awareness, ease-of-use of technology and taxcompliance costs on tax compliance, namely by increasing the contribution to voluntary tax-compliance for people with high tax-attitude. The samples taken in this study were 99 individual taxpayers who were living in Jakarta and already had a Taxpayer Identification Number. As the result, tax awareness and online perceived ease-of-use only have a significant and positive effect on tax compliance directly. Meanwhile, tax compliance cost has no direct effect on tax compliance. The tax attitude only strengthens the relationship between tax-compliance cost and tax compliance. Meanwhile, tax attitude does not strengthen the relationship between tax awareness and online perceived ease-of-use and tax compliance.
\end{abstract}

Keywords: Tax Compliance, Tax Attitude, Individual Taxpayers

\section{INTRODUCTION}

As the era progresses and to facilitate people in tax payments, the General Directorate of Taxation also provides payment facilities, management, and monitoring of people's taxes online, with the addition of such tax facilities since 2005, although it has not been as easy and effective as it is now.

In 2018, the Indonesia Ministry of Finance issued the Regulation of the Minister of Finance Number 9 Year 2018, on the obligation to use e-filling. As one of the official partners of the General Directorate of Taxation, OnlinePajak also provides the facility of digitally-stored payment and reporting of people's taxes in an electronic storage system. The goal of developing e-filling and ebilling is providing a fully-electronic system, easy service, covering national-wide accepted transactions, coordination, and centralized data management.

There are several issues related to the obligation to pay taxes by the General Directorate of Taxation [1], which are: 1) There are still citizens, both ordinary people, businessmen, and government officials who do not have moral awareness as good and commendable taxpayers, such as corruption, collusion, and nepotism, tax evasion, bribery practices, and other bad behaviours; 2) There are members of public who do not yet understand the importance of taxes, and policies of the use and benefits for the nation and the country; 3) There are cases of State apparatus that do not set an exemplary example in the obligation to pay taxes.

According to Indonesian Taxation Quarterly Report published by the Indonesia Minister of Finance, Indonesia tax receipts have reached Rp248.49 trillion or $15.78 \%$ of the target. However, it was lower than the first quarter of
2018 which reached $17.17 \%$. This indicates that tax receipts in Indonesia are declining and are not in line with the economic growth that is improving at this time, therefore the government needs to anticipate this so that it will not happen again in the future.

The decrease in tax receipts indicates that people's compliance in paying taxes or tax compliance is still very low.

The factor that affects tax compliance is tax awareness, which is a condition whereas a person knows, respects, and complies with the applicable tax regulations and has the sincerity and desire to fulfil his or her tax obligations [2]. People who have high tax-awareness tend to know the reason and confidence that the taxes they pay will be useful to them in the future [3]. Tax compliance costs are a number of costs that must be incurred by taxpayers other than the taxation costs themselves to carry-out the taxation process. The greater the taxpayers' incurred compliance cost will result in the taxpayers being disobedient [4].

Persons with a high tax-attitude usually have an increased contribution to voluntary tax-compliance, such as not recording fictitious income, not charging unnecessary or unrecognized fees on annual returns, not understating the income or sales reported in the annual tax, reporting people who have committing tax evasion, defending people who are subject to tax injustice, realizing that stealing is a serious violation, and behaving appropriately so that tax revenue runs properly. In addition, they also have to pay taxes in accordance with applicable regulations, because these taxes are also very meaningful to local governments themselves.

The relationship between people with high tax-attitude and tax compliance is to increase the contributions to voluntary tax-compliance. 


\section{LITERATURE REVIEW}

\subsection{Tax Awareness}

Tax Awareness according to [5], is a moral obligation owned by every which is applied and associated with fulfilling taxpayer compliance in paying motorized-vehicle taxes. Taxpayer awareness is an effort accompanied by encouragement and willingness to exercise taxation rights and obligations in accordance with the regulations, and it is understood that these regulations must be known, recognized, respected, and obeyed. If the tax regulations are still limited, the awareness of taxpayers is still low. The low awareness of taxpayers is thought to be caused by the lack of knowledge and understanding of tax regulations in force in Indonesia.

According to [6], tax awareness is a condition in which a person knows, recognizes, respects, and complies seriously with the applicable tax-provisions and wishes to fulfill his or her tax obligations. When people know the applicable tax-provisions, they will know the benefits and uses of the taxes, and will know that these taxes will be useful for their future, so they will be more compliant in paying taxes. This will form a positive effect of tax awareness on the compliance of individual taxpayers in paying taxes.

\subsection{Perceived Ease-of-Use}

Perceived ease-of-use by [7] is the belief that using technology will facilitate a job. Perceived ease-of-use has also been found to be an antecedent of technological factors in [8]. Online perceived ease-of-use is defined as the extent to which potential adopters view the technological usage as a target that is relatively free of effort. When someone feels that the online-tax system is easy to use, that person will tend to be more interested in paying taxes because of the ease of paying taxes. This has a positive effect of perceived ease-of-use on the compliance of individual taxpayers in paying taxes.

The perception of ease-of-use of technology encourages a taxpayer to be able to carry out his or her obligations to pay and report on-time. This variable can be used as a study in increasing one's compliance.

\subsection{Tax-Compliance Cost}

Tax-compliance cost is the cost incurred by taxpayers in paying taxes. Tax-compliance costs are issued exclusively for tax-compliance purposes. Basically, these costs can only be avoided when the taxation is eliminated (Sandford $\&$ Hardwick in [9]). Monetary-compliance costs include real money paid and potential costs related to time and other resources incurred when complying with tax laws. Psychological costs, on the other hand, involve estimating the stress and anxiety that result from complying with tax laws.

\subsection{Tax Attitude}

Tax attitude according to [10] is a question or evaluation whether this will be beneficial or not for taxpayers. If it is profitable, then the taxpayer will carry out his or her tax obligations. Based on the definition above, it can be concluded that tax attitude is the behavior that taxpayers will do in order to comply with the applicable tax laws.

The attitude of taxpayer has an influence on tax compliance, because this is an individual attitude by adjusting to current conditions, for example, by having the attitude that the taxes we pay later will be useful not only for ourselves, but also for other people. Usually, taxpayers will tend to comply with the existing taxation [11]. The attitude of taxpayers will affect tax compliance, because by increasing the socialization of the importance of paying taxes, it can increase the tax awareness, because the attitude of taxpayers can be influenced by awareness, convenience, and costs.

\subsection{Tax Compliance}

Compliance with taxes is the responsibility to God, by the government and the people as taxpayers in fulfilling all forms of taxation obligations and exercising their share of tax rights. The awareness itself is an encouragement from each individual and motivation that comes from the environment outside the individual itself, for example, encouragement from taxation officials such as the General Director of Taxes that modifies the tax system in form of improving services for taxpayers through various types of services in form of e-systems. such as e-registration, efilling, e-SPT, e-billing, etc. This is done so that taxpayers can register, fill the SPT online, and by themselves, this is in accordance with what is regulated in the Compliance Theory.

There are two types of taxpayer compliance [12]. The first is formal compliance and the second is material compliance. Formal compliance can be defined as the behavior of taxpayers in which they are obedient in carrying out their obligation to pay taxes in accordance with the law, while material compliance is a condition in which taxpayers substantially fulfill all the contents of the tax law.

\subsection{Research Hypotheses}

According to the literature review, there are six hypotheses in this study, which are shown as follows.

$\mathrm{H}_{1}$ : Tax awareness has a significant and positive effect on tax compliance.

$\mathrm{H}_{2}$ : Online perceived ease-of-use has a significant and positive effect on tax compliance.

$\mathrm{H}_{3}$ : Tax-compliance cost has a significant and negative effect on tax compliance.

$\mathrm{H}_{4}$ : Tax attitude moderates the relationship between tax awareness and tax compliance. 
$\mathrm{H}_{5}$ : Tax attitude moderates the relationship between online perceived ease-of-use and tax compliance.

$\mathrm{H}_{6}$ : Tax attitude moderates the relationship between taxcompliance cost and tax compliance.

The research model in this study is shown in Figure 1 below.

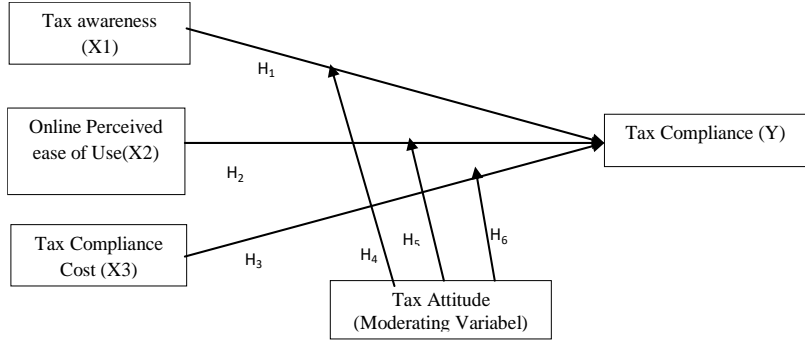

Figure 1 Research Model

\section{RESEARCH METHOD}

This research used a quantitative research method using primary data. Respondents were asked to give their opinion on the indicators related to the variables being tested in the questionnaire. Respondents stated their level of agreement with the statement based on five-scale choices based on the Likert-scale. The population used in this study is the individual taxpayers registered at the TaxService Office (TSO) in Jakarta Special Region, who already have the Taxpayer Identification Number.

\section{RESULTS AND DISCUSSIONS}

The validity of this study was measured using the SmartPLS version 3 data processing program in which the program has two validity criteria, namely convergent validity and discriminant validity. Through the validity analysis using 99 respondents, if they pass the test, the next test will be carried out, namely data reliability analysis. The validity analysis is viewed from two criteria, namely: convergent validity and discriminant validity.

All indicators used by the research latent variables, which are tax awareness, online perceived ease-of-use, taxcompliance cost, tax compliance, and tax attitude are valid by using the convergent validity, because each AVE value in each variable is greater than 0.5. After that, the discriminant validity test was carried out by each indicator used to produce the highest outer-loading value on its own variable compared to the outer-loading on other variables, which means that the results are valid. So, the test could be continued to the next stage, namely the reliability test.

The reliability in this study was measured using Cronbach's Alpha and composite reliability. Based on the results conducted, all indicators used by the research's latent variables are reliable, because they produce the Cronbach's Alpha and composite reliability higher than 0.6. Further tests were performed, namely the Coefficient-
of-Determination, q-square, f-square, Goodness-of-Fit (GoF) test, Path Coefficients, and Hypothesis Tests.

Based on the tests carried out, the Adjusted R-Square value / Coefficient-of-Determination is 0.843 , which indicates that the proportion of the independent variables in influencing the dependent variable is $84.3 \%$. The results of the interpretation of this value stated that $84.3 \%$ of variation in the dependent variable, namely tax compliance, is influenced by the independent variables simultaneously, namely tax awareness, online perceived ease-of-use, and tax-compliance cost. Then the remaining $15.7 \%$ of variation in the tax compliance variable is influenced by other independent variables not included in this study.

To test the predictive relevance of constructs, Predictive Relevance or Q-Square is used. Based on the results of data processing, the research construct used has predictive relevance, because it produces a q-square value of 0.482 (higher than 0). Then, the result of predictive relevance belongs to the "high-effect-size" category. So, the research construct is good-for-use in measuring the research phenomena.

In assessing the size of the influence of a predictor, the fsquare approach was used. The effect size is used to measure the size of the positive predictor capability. Based on the test results, it is known that the value of $\mathrm{f}^{2}$ in each of the independent variables toward the dependent variable is 0.090 , from the variable of tax awareness $\left(\mathrm{X}_{1}\right)$ to tax compliance (Y), which means that tax awareness has a small effect on tax compliance. Then, the $\mathrm{f}^{2}$ value is 0.188 , from the online perceived ease-of-use $\left(\mathrm{X}_{2}\right)$ toward tax compliance (Y), meaning that online perceived ease-of-use has a moderate effect on tax compliance. Furthermore, the value of $\mathrm{f}^{2}$ is 0.011 , from the tax-compliance cost variable $\left(\mathrm{X}_{3}\right)$ on tax compliance $(\mathrm{Y})$, meaning that the taxcompliance cost has no effect on tax compliance. Last, the value of $\mathrm{f}^{2}$ is 0.223 , from the variable of tax attitude (M) towards tax compliance (Y), meaning that the tax attitude has a moderate effect on tax compliance.

The Goodness-of-Fit (GoF) test aims to determine how feasible the research model that has been formed to be used in a study. Based on data analysis, it is known that the value of Goodness-of-Fit (GoF) is 0.691 (greater than 0.36 ), so the level of suitability between the measurement model and the structural model in this study is "large". Next, the path-coefficient tests were conducted. Based on the tests carried out, it is known that the path-coefficient values of the independent variables, namely tax awareness $\left(\mathrm{X}_{1}\right)$ and online perceived ease-of-use $\left(\mathrm{X}_{2}\right)$ are positive toward the dependent variable, namely tax compliance, because it is greater than zero.

Meanwhile, the independent variable of tax-compliance cost $\left(\mathrm{X}_{3}\right)$ is negative toward tax compliance, because it is less than 0 . So, the effect is negative. Then, the path coefficient in hypothesis 4 (moderation-effect) produces a value of 0.093 , which means that the tax attitude positively moderates or strengthens the relationship between tax awareness and tax compliance. The path coefficient in hypothesis 5 (moderation-effect) produces a value of 0.049 , which means that the tax attitude moderates 
negatively / weakens the relationship between online perceived ease-of-use and tax compliance. Last, the path coefficient in hypothesis 6 (moderation-effect) produces a value of 0.119 , which means that tax attitude positively moderates or strengthens the relationship between taxcompliance cost and tax compliance.

The first hypothesis stating that "Tax awareness has a significant and positive effect on tax compliance" was not rejected, because it produces a beta value of 0.254 (greater than 0 ) which indicates a positive prediction, and a tstatistics value of 1.938 (higher than 1.645) and a p-value of 0.027 (less than 0.05), which means the effect is significant. So, based on the calculation result with the bootstrapping method, it is known that if the tax awareness variable increases by one unit and the other independent variables are considered constant, it will increase the tax compliance variable by 0.254 . So, it can be stated that when tax awareness increases, tax compliance will also increase.

The second hypothesis stating that "Online perceived easeof-use has a significant and positive effect on tax compliance" was not rejected, because it produces a beta value of 0.393 (greater than 0 ) which indicates a positive prediction, and a t-statistics value of 3.006 (higher than 1.645 ) and a p-value of 0.001 (less than 0.05), which means that the effect is significant. So, based on the calculation result with the bootstrapping method, it is known that if the online perceived ease-of-use variable increases by one unit and the other independent variables are considered constant, it will increase the tax compliance variable by 0.393 . So, it can be noted that when online perceived ease-of-use increases, tax compliance will also increase.

The third hypothesis stating that "Tax-compliance cost has a significant and negative effect on tax compliance" was rejected, because although it produces a (negative) beta value of -0.041 (less than 0 ) which indicates a negative prediction, but it generates a t-statistics value of 0.691 (less than 1.645) and a p-value of 0.245 (greater than $0.05)$, which means that the effect is insignificant. So, based on the calculation result with the bootstrapping method, it is known that the effect is negative but insignificant. Thus, it is denoted that the third hypothesis was rejected.

The fourth hypothesis stating that "Tax attitude moderates the relationship between tax awareness and tax compliance" results a beta value of 0.093 , but it was rejected, because it produces a t-statistics value of 0.752 (less than 1.645) and a p-value of 0.226 (greater than $0.05)$, which means that the effect is insignificant. So, based on the calculation result with the bootstrapping method, it is known that tax attitude moderates the relationship between tax awareness and tax compliance positively but not significant. Thus, it is denoted that the fourth hypothesis was rejected.

The fifth hypothesis stating that "Tax attitude moderates the relationship between online perceived ease-of-use and tax compliance" results beta value of -0.049 , but it was rejected, because it produces a t-statistics value of 0.412 (less than 1.645) and a p-value of 0.340 (greater than
0.05), which means that the effect is insignificant. So, based on the calculation result with the bootstrapping method, it is known that tax attitude moderates the relationship between online perceived ease-of-use and tax compliance negatively and insignificantly. Thus, it is denoted that the fifth hypothesis was rejected.

The sixth hypothesis stating that "tax attitude moderates the relationship between tax-compliance cost and tax compliance" results a beta value of 0.119 , which was not rejected, because it produces a t-statistics of 1.806 (greater than 1.645) and a p-value of 0.036 (less than 0.05), which means that the effect is significant. So, based on the calculation results with the bootstrapping method, it is known that tax attitude can moderate the relationship between tax-compliance cost and tax compliance significantly. Thus, it is notified that tax attitude will strengthen the relationship between tax-compliance cost and tax compliance.

Tax awareness and online perceived of ease-of-use of technology encourage taxpayers to obey their obligations. So, the result of this study has a significant and positive effect on tax compliance. This result is supported by previous research by [10], concluding that the taxpayers' awareness variable has a significant effect on taxpayers' compliance. A good taxpayer's attitude can be reflected in the behavior of a person in paying and reporting taxes correctly and on-time. It is proven that the tax attitude will strengthen the relationship between tax-compliance cost and tax compliance. According to [10], this proves that attitude has an important role in the behavior to carry out an action that is obedient, particularly in relation to the consciousness of paying taxes. The attitude of taxpayers shows that the taxpayers, who either should perform an action or should adhere to the existing provisions, are compulsory in undergoing the obligation to pay taxes.

\section{CONCLUSIONS}

In this study, tax awareness has a significant and positive effect on tax compliance. Meanwhile, online perceived ease-of-use has a significant and positive effect on tax compliance. This is because the level of individual confidence in taxes is much more concerned than that in previous years. Meanwhile, the tax-compliance cost variable has a negative direction, but not significant, on tax compliance. Tax-compliance costs incurred exclusively are not intended for tax-compliance purposes; every year it is increasing, but it is very difficult for every taxpayer to pay the taxes honestly and transparently.

For research results, tax attitude cannot moderate the relationship between tax awareness and tax compliance. Furthermore, tax attitude cannot moderate the relationship between online perceived ease-of-use and tax compliance. This means that the obedient taxpayers' attitude cannot strengthen the relationship between the level of taxpayer awareness and the ease-of-use of technology to comply with tax obligations. For the sixth hypothesis, tax attitude can moderate the relationship between tax-compliance cost and tax compliance in a positive and significant way. This 
means that the obedient taxpayers will not incur large costs to comply with their tax obligations.

The suggestion for the next study is expected to adding other variables that can affect tax compliance. The examples of other variables are tax justice and income level, and subsequent research is suggested to be conducted with case studies outside Jakarta, such as Bogor, Tangerang, and Bandung areas.

\section{REFERENCES}

[1] Tim Edukasi Perpajakan Direktorat Jenderal Pajak, Kesadaran Pajak untuk Perguruan Tinggi, Direktorat Jenderal Pajak Kementerian Keuangan Republik Indonesia, 2016.

[2] Negara. H. K., \& Purnamasari, D. I., The Effect of Tax Knowledge, Tax Awareness and Fiscal Service on Taxpayer Compliance (A Study of MSMEs in the Special Region of Yogyakarta), Journal of Computer Science and Network, 2019, pp. 398-402.

[3] Tambunan. V, Pengaruh Kesadaran Pajak Terhadap Kepatuhan Wajib Pajak Dengan Pelayanan Wajib Pajak Sebagai Variabel Intervening Pada Usaha Kecil Menegah (UKM) Yang Terdaftar di KPP Pratama Batam, Jurnal Akuntansi, 2019, pp. 171-180.

[4] Antika. F. N, Budiman. N. A, \& Mulyani. S., Kepatuhan Wajib Pajak UMKM di Kabupaten Kudus Selama Pandemi Covid-19, Seminar Nasional Manajemen, Ekonomi dan Akuntansi Fakultas Ekonomi dan Bisnis UNP Kediri, 2020, pp. 408-417.

[5] Asrinanda. Yoshi Diantimala, The Effect of Tax Knowledge, Self Assessment System, and Tax Awareness on Taxpayer Compliance, International Journal of Academic Research in Business and Social Sciences, 8(10), 2018, pp. 539-550.

[6] Muliari. Ni Ketut, \& Setiawan. Putu Ery, Pengaruh Persepsi Tentang Sanksi Perpajakan Dan Kesadaran Wajib Pajak Pada Kepatuhan Pelaporan Wajib Pajak Orang Pribadi Di Kantor Pelayanan Pajak Pratama Denpasar Timur, Jurnal Ilmiah Akuntansi dan Bisnis, [S.1.], Jan. 2011. ISSN 2303-1018.

[7] Dewi. L.G.K. Ni, \& Mertha. Made, Pengaruh Perceived Usefulness, Perceived Ease-of-Use dan Penggunaan Software Audit pada Kinerja Auditor Internal, E-Jurnal Akuntansi Universitas Udayana, Vol.17.2, November 2016, pp. 1485-1515. ISSN: 23028556

[8] Mustapha. Bojuwon, \& Obid. Siti Normala Bt. Sheikh, Tax Service Quality: The Mediating Effect of
Perceived Ease of Use of the Online Tax System, Procedia - Social and Behavioral Sciences, 172, 2015, pp. 2-9. DOI: 10.1016/j.sbspro.2015.01.328

[9] Mahangila. Deogratus, \& Anderson. Wineaster, Tax Administrative Burdens in the Tourism Sector in Zanzibar: Stakeholders' Perspectives, SAGE Open 7 (4) Volume: 7 issue: 4, 2017, pp. 1-17. DOI: https://doi.org/10.1177/2158244017736800

[10] Lestari. T, \& Wicaksono. M, Effect of Awareness, Knowledge, and Attitude of Taxpayer Tax Compliance For Taxpayer in Tax office in Boyolali, International Journal of Economics, Business and Accounting Research, 2017, pp. 12-25.

[11] Kemala. W, Pengaruh Kesadaran Wajib Pajak, Pengetahuan Pajak, Sikap Wajib Pajak dan Reformasi Administrasi Perpajakan Terhadap Kepatuhan Wajib Pajak Kendaraan Bermotor, Journal of Accounting, 2015, pp. 1-15.

[12] Devano. S, \& Rahayu. S. K, Perpajakan: Konsep, Teori, dan Isu, Kencana Prenada Media Group, Jakarta, 2010 . 